\title{
E-LEARNING DENGAN MENGGUNAKAN COI FRAMEWORK
}

\author{
Lydiawati Kosasih; Muhammad Iqbal \\ Information Systems Department, School of Information Systems, Binus University \\ Jl. K.H. Syahdan No. 9, Palmerah, Jakarta Barat 11480 \\ lkosasih@binus.edu
}

\begin{abstract}
This study discusses some considerations in education to achieve a good quality of learning by utilizing technological advances such as E-Learning. This study uses a model of Community of Inquiry (COI) as a comparative study to improve the quality of E-Learning program. Implementation of COI model in discussion forum on BiNusMaya through E-Learning is able to improve the quality of a discussion as improvement of knowledge management. This study aims to provide a proposal to the Department of Information Systems Bina Nusantara University in enhancing the effectiveness of the use of discussion forums on BiNusMaya (ELearning). By presenting the survey results related to the Binusmaya current condition,s such constraints and development expectations of both the lecturers and students for Binusmaya can be described. In addition, the application of CoI model is presented in a learning process especially when meeting outside of class (without face-to-face). The results of this study is expected to be the basis for developing a COI model design and implementation plan in Management Information Systems course, that may improve the quality of the use of discussion forums as part of the knowledge management process in future study.
\end{abstract}

Keywords: e-learning, qualities, COI models

\begin{abstract}
ABSTRAK
Penelitian ini membahas beberapa pertimbangan dalam dunia pendidikan untuk mencapai pembelajaran dengan kualitas yang baik dengan memanfaatkan kemajuan teknologi seperti E-Learning. Penelitian ini menggunakan model Community of Inquiry (CoI) sebagai studi banding untuk meningkatkan kualitas dari program E-Learning. Penerapan model CoI di dalam forum diskusi melalui E-Learning akan meningkatkan kualitas dari sebuah diskusi sebagai peningkatkan dari knowledge management. Penelitian ini bertujuan untuk memberikan usulan kepada Jurusan Sistem Informasi Universitas Bina Nusantara dalam meningkatkan efektivitas pemakaian forum diskusi pada BiNusMaya (E-Learning). Dengan menyajikan hasil survei terkait kondisi Binusmaya saat ini, dapat dipaparkan hambatan yang dialami dan harapan pengembangan dari Binusmaya baik dari sisi Dosen maupun Mahasiswa. Selain itu, disajikan penerapan model CoI dalam suatu proses pembelajaran khususnya ketika pertemuan di luar kelas (tanpa tatap muka). Diharapkan dari hasil penelitian ini dapat menjadi landasan untuk mengembangkan rancangan model CoI dan rencana penerapannya pada mata kuliah Sistem Informasi Manajemen, sehingga meningkatkan kualitas penggunaan forum diskusi sebagai bagian dari knowledge management proses pada penelitian selanjutnya.
\end{abstract}

Kata kunci: e-learning, kualitas, model CoI 


\section{PENDAHULUAN}

Sejalan dengan perkembangan teknologi yang semakin canggih pada saat ini dan penetrasinya hampir ke seluruh aspek kehidupan termasuk dalam dunia pendidikan. Bersamaan pula pada saat ini di dunia pendidikan mulai dari sekolah sampai penguruan tinggi banyak yang telah menggunakan teknologi sebagai salah satu alat untuk mencapai keunggulan yang kompetitif. Bermula dari penggunaan teknologi sebagai alat bantu dalam kegiatan administrasi sekolah, kemudian mendukung pembuatan bahan ajar baik tahap pembuatan maupun penyampaiannya, dan sampai pada tingkat yang lebih tinggi yaitu pelebaran dan pendalaman dari makna pendidikan itu sendiri, sehingga dengan pemanfaatan teknologi ini, proses belajar tidak lagi terbatas ruang dan waktu, istilah yang kita pakai untuk menyatakan hal ini adalah e-learning atau terminologi lain menyebutnya dengan blended learning.

Menurut Osguthorpe \& Graham (2003), blended learning diartikan sebagai pencampuran yang mendalam dari pengalaman tatap muka dan pembelajaran online. Kerres \& Witt (2003) menginterpretasikan blended learning sebagai campuran metode pendidikan dan format penyampaiannya. Tahun 2006, Mason and Rennie menjelaskan blended learning adalah kombinasi dari pembelajaran secara online dan tatap muka, yang selanjutnya untuk mengakomodasi kombinasi yang lebih kompleks, seperti pencampuran dari mode komunikasi yang langsung dan tidak langsung, serta diskusi yang formal dan tidak formal dan campuran metode penyampaian materinya. Pada saat ini metode pembelajaran Blended learning sangat diminati, terutama di pendidikan perguruan tinggi. Menurut penelitian yang diadakan oleh Bonk, C. J.\& Graham, C. R. didapatkan 93\% perguruan tinggi menggunakan blended learning sebagai salah satu strategi di institusi mereka yang digunakan oleh dosen dan staf jurusan. 7 dari 10 perguruan tinggi mengharapkan lebih dari 40\% mata kuliah mereka diselenggarakan secara blended learning pada tahun 2013. Namun pada kenyataannya, belum semua dosen memanfaatkan teknologi sebagai sebuah alat dan sarana untuk meningkatkan proses belajar mengajar. Kurang optimalnya pemanfaatan ini dilatarbelakangi oleh banyak alasan, diantaranya kurangnya kemampuan dalam menggunakan teknologi, sulitnya merubah kebiasaan cara mengajar, dan kurangnya informasi akan manfaat dari teknologi. Tapi, kita tahu sekarang bahwa banyak sekali keuntungan yang dapat kita ambil dengan memanfaatkan teknologi secara benar dan tepat dalam kegiatan proses belajar mengajar kita.

Jika diamati saat ini sudah banyak proses pembelajaran jarak jauh (tanpa tatap muka) yang diterapkan di dunia pendidikan, baik formal maupun informal, fenomena ini terjadi baik di negara barat maupun Asia, termasuk Indonesia. Media yang digunakan untuk pembelajaran jarak jauh ini bervariasi, dari yang mulai menggunakan aplikasi yang dijual bebas, sampai dengan aplikasi build in sesuai dengan kebutuhan dari Institusi pendidikan tersebut. Sistem pembelajaran di BINUS UNIVERSITY (BINUS) dilandasi dengan aplikasi Learning Management System yaitu BiNusMaya. BiNusMaya sudah mulai diterapkan di BINUS mulai tahun 2002. Awal penerapannya BiNusMaya hanya digunakan oleh kelas-kelas tertentu yang sampai akhirnya diterapkan untuk hampir seluruh mata kuliah dan oleh seluruh Dosen. Yang mana workshop terkait penggunaan BiNusMaya telah dimasukkan dalam bahan Induksi yang wajib diikuti oleh seluruh dosen di BINUS.

\section{METODE}

\section{Community of Inquiry (CoI)}

Sebuah Community of Inquiry bergantung pada kelangenggan suatu komunikasi dan kolaborasi di mana semua pesertanya, baik dosen dan siswa berbagi pengalaman dan pandangan 
mereka. Mereka diharapkan untuk dapat aktif dan fokus pada topik dan tugas yang sedang dibahas terkait mata kuliahnya

Proses pembelajaran mendefinisikan proses bertanya merupakan sesuatu yang melebihi dari sekedar cara akses atau bahkan asimilasi informasi. Proses bertanya menggabungkan proses belajar dan hasil pembelajaran menjadi satu kesatuan yang terus dapat berulang. Proses bertanya menghubungkan refleksi pribadi dan materi dengan mendorong siswa untuk mengeksplore secara kolaborasi bersama-sama dalam grup dan memberikan pertanyaan yang mendalam dan masuk akal dari materi pembahasan yang ada, sehingga proses bertanya yang benar adalah terjadinya refleksi dari hasil diskusi tanya jawab dan mendapat pembelajaran dari pengalaman pada proses tersebut. Proses bertanya harus memiliki tujuan, tapi juga flesibel, untuk mengekplorasi ketertarikan yang belum terlihat dari proses tersebut. Hubungan personal punya peranan penting dalam sebuah Community of Inquiry, tapi itu bukan merupakan tujuan akhirnya.

Kerangka Community of Inquiry (CoI) (Gambar 1) menyediakan urutan dan panduan untuk melakukan eksplorasi pada desain blended learning dengan menghadirkan proses dan hasil pembelajaran yang terbentuk secara koheren dan akurat.

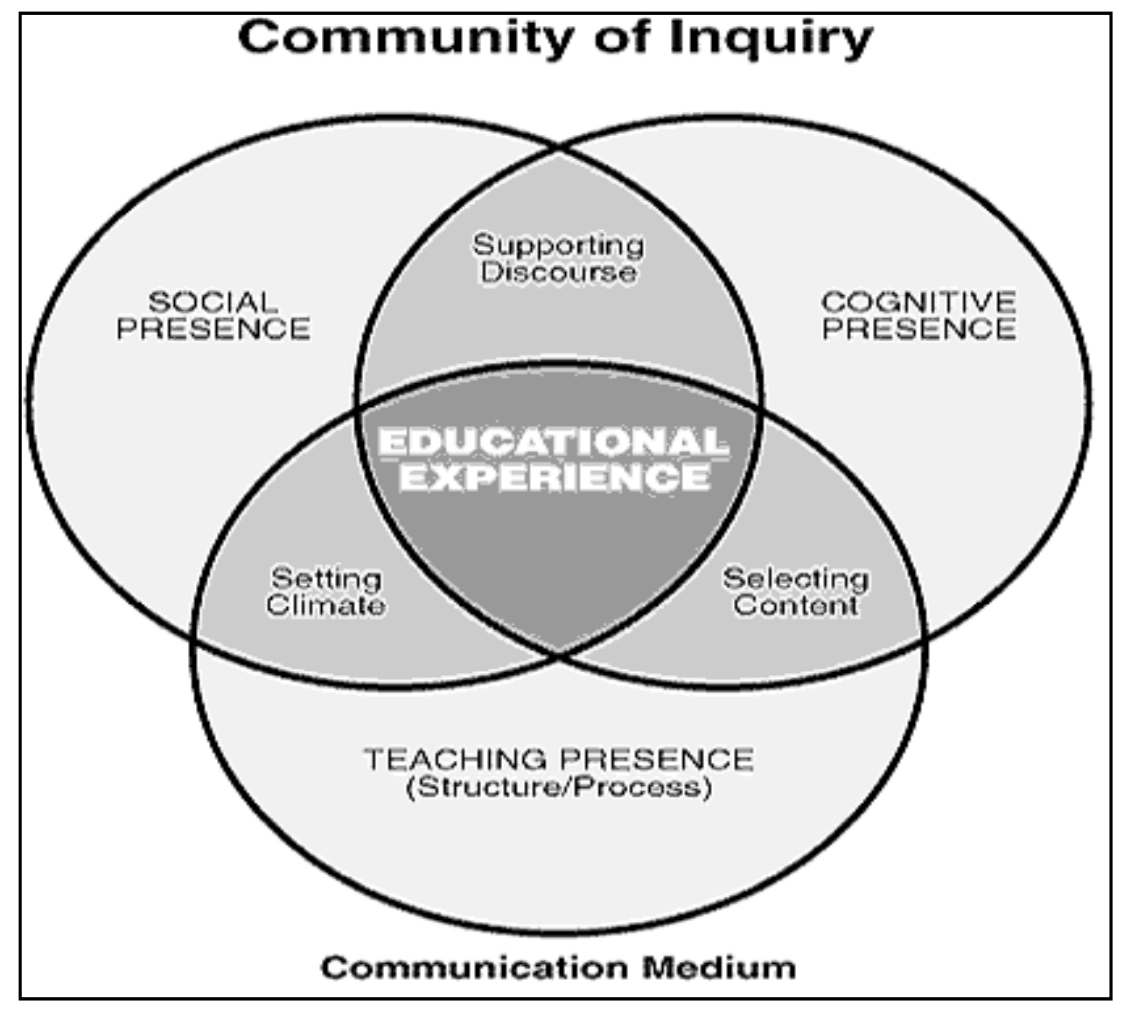

Gambar 1 Kerangka Community of Inquiry (CoI)

Seperti sudah disebutkan diatas, kerangka CoI menyediakan urutan secara konseptual dan hal tersebut telah terbukti menunjukkan validitas empiris yang kuat (Arbaugh, 2007; Garrison, ClevelandInnes \& Fund, 2004). Kerangka CoI adalah sebuah model berulang untuk setiap elemen intinya dan saling mendukung satu sama lain, seperti yang dilihat pada Gambar 2.0. Tiga elemen dari kerangka CoI adalah adanya hubungan sosial (social presence), adanya tingkat pemahaman yang dicapai (cognitive presence), dan metode mengajar yang tepat (teaching presence). Masing-masing elemen mencerminkan kategori dan indikator yang biasa digunakan pada proses belajar mengajar. 


\begin{tabular}{cll}
\hline Elements & Categories & Indicators (examples only) \\
\hline Social & Open communication & Enabling risk-free expression \\
presence & Group cohesion & Encouraging collaboration \\
& Affective/personal & Expressing cmotions, camaraderie \\
Cognitive & Triggering cvent & Having sense of puzzlement \\
presence & Exploration & Exchanging information \\
& Integration & Connecting ideas \\
& Resolution & Applying new ideas \\
Teaching & Design \& otganization & Sctting curriculum and methods \\
presence & Facilitation of discourse & Sharing personal meaning \\
& Direct instruction & Focusing discussion \\
\hline
\end{tabular}

Gambar 2 Community of Inquiry Framework

Merupakan hal yang sangat penting untuk mengerti ketiga elemen tersebut saling bergantung, bahwa satu elemen dapat mempengaruhi elemen yang lainnya. Sebagai contoh, metode pengajaran akan sangat berdampak dan mempengaruhi pencapai tingkat pemahaman materi yang dibahas, dan hubungan sosial yang terjalin dapat komunikasi atau kelas tersebut juga dapat mempengaruhi siswa untuk mencapai tujuan pembelajaran. Di bagian selanjutnya kita akan membahas satu per satu dari setiap elemen yang ada.

Hasil dari wawancara, observasi dan kuesioner pada tahap pengumpulan data ini akan menjadi dasar informasi untuk merancang model CoI dan implementasinya.

\section{HASIL DAN PEMBAHASAN}

\section{Hubungan Social (Social Presence)}

Sebagai makhluk sosial, kebutuhan mendasar manusia adalah untuk dapat berinteraksi dan menjalin komunikasi dengan sesamanya. Untuk membuat suatu hubungan yang baik dan berkelanjutan membutuhkan sebuah komunikasi yang terbuka di mana ada rasa saling percaya satu dengan yang lainnya. Dalam hal social presence pada model blended learning, memiliki pemahaman dasar yang sama, jika seorang dosen ingin memelihara relasi dan komunikasi yang baik dengan siswa, harus tercipta dulu situasi yang kondusif, adanya respon yang positif, koneksi personal dan komunikasi yang afektif, seperti yang terlihat pada gambar 3. Kategori ini harus ada, dipertahankan dan harus dapat dikembangkan dalam sebuah CoI.

Dosen memiliki tanggung jawab dapat menciptakan suasana yang kondusif dan mampu membina relasi baik dirinya dengan siswa, maupun hubungan yang terjalin antar siswa. Walaupun pada kenyataannya hal ini membutuhkan waktu yang cukup untuk siswa dapat merasa nyaman dan percaya pada komunitas atau kelas tersebut, namun demikian hal ini bisa terjadi dengan memperhatikan juga keterikatan emosi dan persahabatan yang ada akan menciptakan hubungan sosial dan komunitas edukasi yang baik.

Dengan adanya relasi seperti ini juga menciptakan rasa memiliki satu sama lain dalam kelas tersebut, saling mendukung dalam mengekpresikan kebebasan berpendapat, dan memelihara kesatuan, karena CoI khususnya elemen social presence ini tidak sama dengan diskusi online biasa. 
Prinsip yang dapat kita terapkan adalah sebagai dosen, yang pertama kita harus menciptakan iklim yang kondusif dikelas, dengan demikian diharapkan siswa tidak takut untuk berpendapat, mereka dapat mengemukakan pendapat mereka dengan bebas dan terbuka, sebagai tanda proses pembelaran mulai terjadi; dan kedua kita dapat memberikan respon yang positif dari diskusi yang terjadi, sehingga rasa percaya dan nyaman dapat mulai dirasakan oleh siswa, dengan demikian mereka akan terus berani mengemukakan pendapat mereka; dan yang ketiga untuk keberlanjutan sampai pada akhir semester, kita dapat membuat komitmen kelas secara bersama-sama, tentu saja dengan dipimpin oleh dosen, yang mencakup apa, kenapa dan bagaimana kita akan menjalankan perkuliahan ini baik secara tatap muka maupun sesi online.

\section{Pencapaian Tingkat Pemahaman (Cognitive Presence)}

Sebagai bagian dari proses belajar mengajar, apapun media yang digunakan itu haruslah mendukung terjadinya transformasi pengetahuan (knowledge), kemampuan (skill) dan sikap (attitude). Dalam memberi perhatian yang besar pada tranformasi peningkatkan pemahaman, proses bertanya (inquiry) sangat berkaitan erat, mulai dari dipicu dengan pertanyaan yang kritis dan menyelidik hingga menuju simpulan untuk beberapa alternatif solusi. Pada umumnya setiap mata kuliah sudah ada tujuan dan hasil pembelajaran yang akan dicapai baik secara umum maupun setiap sesinya, dan proses bertanya atau diskusi harus tetap pada ranah tersebut sehingga tidak melebar dan pencapaian hasilnya dapat diukur.

Garrison and Vaughan (2010) menjelaskan penerapan proses bertanya atau diskusi memiliki 2 dimensi dan 4 tahapan seperti yang terlihat pada Gambar 3. Garis vertikal menunjukkan proses mempertimbangkan untuk pengambilan keputusan. Hal ini menunjukkan proses berulang yang alami dari proses diskusi dalam menghadirkan baik aktivitas pemahaman bertingkat dan pemikiran yang didapat dari hasil kolaborasi. Garis horizontal menunjukkan gambaran dari persepsi yang diterima akibat dari diskusi yang terjadi. Hal ini terjadi karena adanya proses pemahaman yang bertingkat dari sharing pengalaman diskusi yang terjadi.

Cognitive presence adalah sebuah proses yang berulang, di mana siswa melakukan pertukaran informasi, menghubungan ide dan gagasan satu sama lain, menciptakan konsep yang baru, dan mencoba kebenaran dari alternatif solusi yang disimpulkan, dan terkadang mereka diharuskan lebih memfokuskan diri untuk melakukan eksplorasi lebih lanjut, dari ide, gagasan atau solusi yang dipilih.

Pada program blended learning, siswa memiliki kesempatan untuk meningkatkan proses belajar mereka dengan mengintegrasikan komunikasi verbal dan tertulis, di mana kita ketahui perpaduan dari kedua proses ini memberikan hasil yang positif bagi siswa dalam mereka mendapatkan ilmu tersebut.

Prinsip yang dapat kita lakukan untuk tahap cognitive presence sebagai dosen adalah pertama kita harus merencanakan saat-saat siswa dapat melakukan refleksi yang kritis dari materi bahasan yang ada, kedua memanfaatkan forum diskusi sebagai perpanjangan diskusi yang terjadi di kelas, dan terakhir memberikan tugas-tugas yang mendukung proses bertanya atau berdiskusi itu dapat terjadi. Sebagai bagian dari proses pembelajaran, dosen diharuskan memberikan umpan balik dan rangkuman dari setiap proses diskusi yang terjadi. Dosen juga diharapkan memberikan pertanyaan atau pernyataan awal, yang menyebabkan siswa mulai dapat berpikir kritis dan dilanjutkan dengan proses diskusi diantara siswa. Proses diskusi ini dapat dibuat per-individu ataupun grup, untuk kasus kelas besar akan lebih sering menggunakan diskusi grup, di mana aturan untuk hal ini harus dipahami dan diketahui siswa dari awal, misalnya ada grup yang bertugas memberikan konsep-konsep terkait dan ada grup yang memberikan fakta-fakta yang ada, dengan demikian diskusi bisa dilanjutkan. 


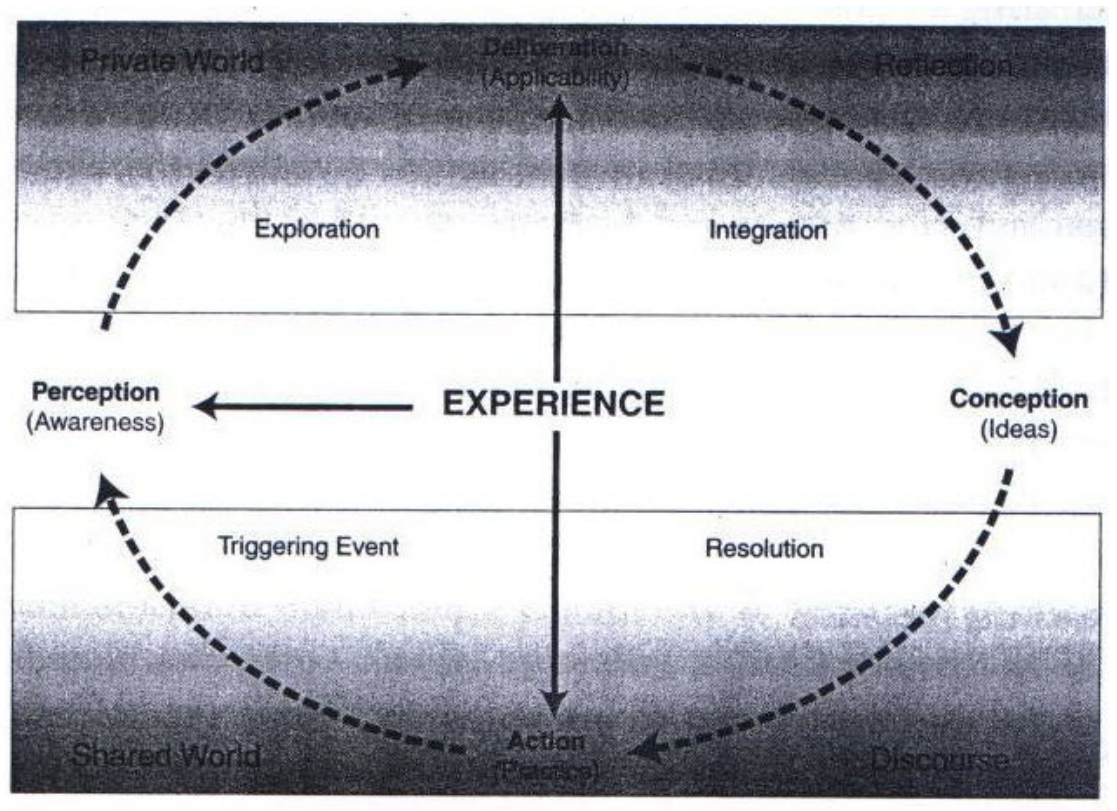

Gambar 3 Practical inquiry model

\section{Metode Penyampaian Materi (Teaching Presence)}

Seperti kita ketahui bahwa baik pada saat sesi tatap muka maupun sesi online, dosen tetap diharuskan mengimplementasikan metode pembelajaran yang baik dan benar, jadi teaching presence merupakan elemen yang penting untuk membuat kedua elemen sebelumnya menjadi suatu yang produktif. Aktivitas pembelajaran yang semula hanya dirancang untuk pembelajaran pada saat sesi tatap muka sekarang juga sudah mulai direncanakan untuk sesi online.

Pada elemen ini, dosen diharapkan dan diminta untuk merancang, memfasilitasi dan mengarahkan agar proses pembelajaran itu dapat terjadi. Dosen berkewajiban untuk mempersiapkan materi dari pokok bahasan yang ada, juga menyediakan cara pendekatan dan metode penyampaian serta aktivitasnya, termasuk menyediakan arahan, panduan dan fokus topik diskusi dan tugas-tugas terkait. Menciptakan materi baik untuk sesi online dan tatap muka yang berkualitas baik merupakan sebuah tantangan bagi dosen. Terlebih lagi hal tersebut membutuhkan sumber-sumber lainnya sebagai materi tambahan yang dapat digunakan sebagai bahan diskusi baik pada saat sesi tatap muka maupun online.

\section{Hasil Survei}

\section{Pengenalan Binus Maya}

Aspek Pengenalan Binus Maya adalah peneliti ingin mengetahui seberapa mengerti pengguna/ mahasiswa dapat mengenal Binus Maya yang dijadikan sebagai fasilitas belajar mengajar dalam penggunaan e-learning. Sehingga diharapkan dengan mengetahui aspek ini, maka pengguna/ mahasiswa dapat mengerti semua pengenalan fitur di dalam Binus Maya.

Di bawah ini adalah hasil rekap dari survei tentang pengenalan binus maya yang dilakukan (Tabel 1 dan 2): 
Tabel 1 Hasil Survei Dosen: Pengenalan Binus Maya

\begin{tabular}{|c|c|c|c|c|c|c|}
\hline & Komponen & STS & TS & $\mathbf{N}$ & $\mathrm{S}$ & SS \\
\hline A1 & mengetahui alamat situs Binus Maya dengan tepat & $0 \%$ & $0 \%$ & $0 \%$ & $18 \%$ & $82 \%$ \\
\hline A2 & $\begin{array}{l}\text { mudah mengunjungi situs Binus Maya dalam hal akses } \\
\text { melalui internet }\end{array}$ & $0 \%$ & $0 \%$ & $0 \%$ & $27 \%$ & $73 \%$ \\
\hline A3 & $\begin{array}{l}\text { mudah mendapatkan informasi apapun dari Binus } \\
\text { Maya }\end{array}$ & $9 \%$ & $9 \%$ & $27 \%$ & $36 \%$ & $18 \%$ \\
\hline
\end{tabular}

Tabel 2 Hasil Survei Mahasiswa: Pengenalan Binus Maya

\begin{tabular}{llccccc}
\hline & Pengenalan Binus Maya & STS & TS & N & S & SS \\
\hline A1 & mengetahui alamat situs Binus Maya dengan tepat & $1 \%$ & $3 \%$ & $7 \%$ & $28 \%$ & $\mathbf{6 1 \%}$ \\
\hline A2 & $\begin{array}{l}\text { mudah mengunjungi situs Binus Maya dalam hal akses } \\
\text { melalui internet }\end{array}$ & $3 \%$ & $8 \%$ & $22 \%$ & $\mathbf{3 7 \%}$ & $29 \%$ \\
\hline A3 & mudah mendapatkan informasi apapun dari Binus Maya & $3 \%$ & $9 \%$ & $32 \%$ & $\mathbf{3 8 \%}$ & $17 \%$ \\
\hline
\end{tabular}

Kedua tabel di atas hampir menunjukkan hasil yang sama, di mana di atas 61\% pemakai sangat setuju telah mengetahui alamat binusmaya, artinya binusmaya telah dikenal atau diketahui oleh pemakai untuk dapat di akses, seperti yang diketahui bersama bahwa alamat Binus Maya Universitas Bina Nusantara adalah http://binusmaya.binus.ac.id. Namun demikian dari sisi mahasiswa ada 1\% yang tidak mengetahui alamat binusmaya.

Lebih dari 37\% menyatakan setuju mudah untuk mengunjungi situs binusmaya, Hal ini berarti ada sebagian mahasiswa yang cukup susah dalam mengunjungi situs Binus Maya dalam hal akses melalui internet. Namun demikian dari sisi mahasiswa ada 3\% yang menyatakan kesulitan untuk dapat mengakses binusmaya.

Pada pernyataan A3, lebih dari 36\% menyatakan setuju mudah mendapatkan informasi dari Binusmaya, meskipun adan 3\% dari sisi mahasiswa yang menyatakan kesulitan mendapatkan informasi dari binusmaya.

Dari ketiga aspek di atas, maka bisa diambil kesimpulan bahwa dalam aspek Pengenalan Binus Maya, mahasiswa sudah cukup mengenai Binus Maya, akan tetapi belum dapat dimanfaatkan secara maksimal karena informasi masih belum maksimal dalam kebutuhan bagi mahasiswa.

\section{Kondisi Binus Maya Saat Ini}

Pada aspek Kondisi Binus Maya saat ini adalah peneliti ingin mengetahui pendapat dari mahasiswa mengenai bagaimana kondisi Binus Maya saat ini yang dapat diterima oleh mahasiswa. Sehingga diharapkan dengan kondisi Binus Maya saat ini, mahasiswa sudah dapat melakukan pembelajaran secara online (e-learning) dapat proses belajar mengajar di luar kelas pun dapat berjalan dengan lancar melalui Binus Maya saat ini.

4):

Dari hasil survei didapat tabel berikut ini mengenai kondisi binus maya saat ini (Tabel 3 dan 
Tabel 3 Hasil Survei Dosen: Kondisi Binus Maya Saat ini

\begin{tabular}{rlccccc}
\hline & Komponen & STS & TS & N & S & SS \\
\hline B1 & $\begin{array}{l}\text { Binus Maya memberikan informasi dengan } \\
\text { sangat lengkap }\end{array}$ & $0 \%$ & $9 \%$ & $\mathbf{1 8 \%}$ & $\mathbf{6 4 \%}$ & $9 \%$ \\
\hline B2 & $\begin{array}{l}\text { kemudahan dalam proses belajar mengajar di } \\
\text { luar kelas seperti penggunaan forum }\end{array}$ & $0 \%$ & $0 \%$ & $9 \%$ & $\mathbf{6 4 \%}$ & $\mathbf{2 7 \%}$ \\
\hline B3 & layanan (service menu) dengan mudah & $0 \%$ & $27 \%$ & $\mathbf{3 6 \%}$ & $\mathbf{2 7 \%}$ & $9 \%$ \\
\hline B4 & $\begin{array}{l}\text { memberikan kebutuhan mahasiswa mengenai } \\
\text { proses belajar mengajar }\end{array}$ & $0 \%$ & $9 \%$ & $\mathbf{1 8 \%}$ & $\mathbf{4 5 \%}$ & $\mathbf{2 7 \%}$ \\
\hline B5 & $\begin{array}{l}\text { menjadi media komunikasi dengan baik antara } \\
\text { dosen dengan mahasiswa }\end{array}$ & $0 \%$ & $18 \%$ & $9 \%$ & $\mathbf{5 5 \%}$ & $\mathbf{1 8 \%}$ \\
\hline
\end{tabular}

Tabel 5 Hasil Survei Mahasiswa: Kondisi Binus Maya Saat ini

\begin{tabular}{|c|c|c|c|c|c|c|}
\hline & Kondisi Binus Maya Saat Ini & STS & TS & $\mathbf{N}$ & $\mathbf{S}$ & SS \\
\hline B1 & $\begin{array}{l}\text { Binus Maya memberikan informasi dengan sangat } \\
\text { lengkap }\end{array}$ & $1 \%$ & $8 \%$ & $31 \%$ & $47 \%$ & $13 \%$ \\
\hline B2 & $\begin{array}{l}\text { kemudahan dalam proses belajar mengajar di luar } \\
\text { kelas seperti penggunaan forum }\end{array}$ & $3 \%$ & $7 \%$ & $26 \%$ & $46 \%$ & $18 \%$ \\
\hline B3 & layanan (service menu) dengan mudah & $2 \%$ & $8 \%$ & $26 \%$ & $48 \%$ & $15 \%$ \\
\hline B4 & $\begin{array}{l}\text { memberikan kebutuhan mahasiswa mengenai } \\
\text { proses belajar mengajar }\end{array}$ & $2 \%$ & $6 \%$ & $23 \%$ & $52 \%$ & $17 \%$ \\
\hline B5 & $\begin{array}{l}\text { menjadi media komunikasi dengan baik antara } \\
\text { dosen dengan mahasiswa }\end{array}$ & $4 \%$ & $14 \%$ & $33 \%$ & $37 \%$ & $13 \%$ \\
\hline
\end{tabular}

Pada pernyataan B1 pada aspek Kondisi Binus Maya saat Ini, lebih dari 47\% responden menyatakan setuju bahwa Binus Maya cukup dapat memberikan informasi dengan sangat lengkap. Hal ini menunjukkan bahwa kondisi Binus Maya saat ini masih belum terlalu lengkap dalam memberikan informasi yang dibutuhkan oleh mahasiswa

Pada pernyataan B2 pada aspek Kondisi Binus Maya saat Ini, lebih dari 46\% responden menyatakan setuju bahwa Binus Maya cukup dapat memberikan kemudahan dalam proses belajar mengajar di luar kelas seperti penggunaan forum. Dengan hal ini menandakan bahwa proses belajar mengajar jika dilakukan di luar kelas masih belum mudah dalam penggunaan di Binus Maya.

Pada pernyataan B3 pada aspek Kondisi Binus Maya saat Ini, lebih dari 27\% responden menyatakan setuju bahwa Binus Maya cukup digunakan dengan mudah dalam layanan (menu di bagian service). Hal ini dapat menunjukkan bahwa mahasiswa masih perlu dibuat layanan Binus Maya agar lebih mudah (user friendly).

Pada pernyataan B4 pada aspek Kondisi Binus Maya saat ini, lebih dari 45\% responden menyatakan setuju bahwa Binus Maya cukup memberikan kebutuhan mahasiswa mengenai proses belajar mengajar. Hal ini menunjukkan bahwa proses belajar mengajar di luar kelas seperti pada forum Binus Maya perlu ditingkatkan lagi sehingga dapat menjadi kebutuhan bagi mahasiswa untuk dapat mendukung proses belajar mengajar di luar kelas. 
Pada pernyataan B5 pada aspek Kondisi Binus Maya saat ini, lebih dari 37\% responden menyatakan setuju bahwa Binus Maya cukup dan perlu ditingkatkan lagi untuk menjadi media komunikasi dengan baik antara dosen dengan mahasiswa. Sehingga dapat dikatakan bahwa saat ini kondisi Binus Maya masih belum digunakan dengan maksimal dalam media komunikasi dengan baik antara dosen dengan mahasiswa.

Maka dari kelima point di aspek ini, dapat kita simpulkan bahwa kondisi Binus Maya saat ini masih perlu mendapatkan perhatian lagi agar mahasiswa merasa bahwa Binus Maya adalah sebagai kebutuhan bagi mahasiswa dan menjadi media yang efektif dalam komunikasi antar mahasiswa dan dosen. Oleh karena itu perlu dilakukan penggunaan Binus Maya yang lebih user friendly sehingga memberikan hasil yang lebih maksimal.

\section{Hambatan Dalam Penggunaan Binus Maya}

Pada aspek Hambatan dalam Penggunaan Binus Maya adalah peneliti ingin mengetahui mengenai hal-hal apa saja yang menjadi hambatan dalam penggunaan Binus Maya. Sehingga diharapkan dengan mengetahui hambatan-hambatan yang ada, dapat dilakukan improvisasi untuk penggunaan Binus Maya di kemudian hari. Dengan demikian maka proses belajar mengajar di luar kelas atau di Binus Maya dapat berjalan lebih maksimal.

Dari hasil survei, didapat tabel berikut ini mengenai Hambatan dalam Penggunaan Binus Maya (Tabel 5 dan 6):

Tabel 5 Hasil Survei Dosen: Hambatan dalam Penggunaan Binus Maya

\begin{tabular}{|c|c|c|c|c|c|c|}
\hline & Komponen & STS & TS & $\mathbf{N}$ & $\mathrm{S}$ & SS \\
\hline $\mathrm{C} 1$ & $\begin{array}{l}\text { menjadi alat bantu komunikasi dalam proses } \\
\text { pembelajaran }\end{array}$ & $0 \%$ & $9 \%$ & $9 \%$ & $64 \%$ & $18 \%$ \\
\hline $\mathrm{C} 2$ & $\begin{array}{l}\text { menjadi alat bantu dalam pembentukan } \\
\text { komunitas bagi dosen dan mahasiswa }\end{array}$ & $0 \%$ & $9 \%$ & $18 \%$ & $55 \%$ & $18 \%$ \\
\hline C3 & $\begin{array}{l}\text { forum diskusi yang dapat membantu } \\
\text { meningkatkan minat belajar }\end{array}$ & $0 \%$ & $18 \%$ & $18 \%$ & $36 \%$ & $27 \%$ \\
\hline $\mathrm{C} 4$ & $\begin{array}{l}\text { forum diskusi yang dapat membantu } \\
\text { meningkatkan pemahaman mahasiswa }\end{array}$ & $0 \%$ & $9 \%$ & $27 \%$ & $55 \%$ & $9 \%$ \\
\hline C5 & $\begin{array}{l}\text { menu Assigment yang dapat membantu dosen } \\
\text { dan mahasiswa dalam pemberian dan penyerahan } \\
\text { tugas }\end{array}$ & $0 \%$ & $9 \%$ & $27 \%$ & $55 \%$ & $9 \%$ \\
\hline C6 & $\begin{array}{l}\text { dapat diakses dengan mudah oleh dosen dan } \\
\text { mahasiswa }\end{array}$ & $0 \%$ & $27 \%$ & $18 \%$ & $27 \%$ & $27 \%$ \\
\hline $\mathrm{C} 7$ & $\begin{array}{l}\text { menyediakan berbagai informasi yang } \\
\text { bermanfaat mengenai proses pembelajaran }\end{array}$ & $0 \%$ & $9 \%$ & $0 \%$ & $45 \%$ & $45 \%$ \\
\hline C8 & $\begin{array}{l}\text { merupakan alat bantu yang menyediakan } \\
\text { berbagai kemudahan dalam penggunaannya }\end{array}$ & $0 \%$ & $9 \%$ & $18 \%$ & $64 \%$ & $9 \%$ \\
\hline C9 & $\begin{array}{l}\text { dapat diakses melalui berbagai web browser } \\
\text { apapun yang tersedia di pasaran }\end{array}$ & $0 \%$ & $18 \%$ & $18 \%$ & $27 \%$ & $36 \%$ \\
\hline
\end{tabular}


Tabel 6 Hasil Survei Mahasiswa: Hambatan dalam Penggunaan Binus Maya

\begin{tabular}{|c|c|c|c|c|c|c|}
\hline & Komponen & STS & TS & $\mathbf{N}$ & $\mathrm{S}$ & SS \\
\hline $\mathrm{C} 1$ & $\begin{array}{l}\text { menjadi alat bantu komunikasi dalam proses } \\
\text { pembelajaran }\end{array}$ & $4 \%$ & $9 \%$ & $31 \%$ & $47 \%$ & $9 \%$ \\
\hline $\mathrm{C} 2$ & $\begin{array}{l}\text { menjadi alat bantu dalam pembentukan komunitas } \\
\text { bagi dosen dan mahasiswa }\end{array}$ & $3 \%$ & $10 \%$ & $36 \%$ & $42 \%$ & $10 \%$ \\
\hline C3 & $\begin{array}{l}\text { forum diskusi yang dapat membantu meningkatkan } \\
\text { minat belajar }\end{array}$ & $3 \%$ & $13 \%$ & $33 \%$ & $41 \%$ & $9 \%$ \\
\hline $\mathrm{C} 4$ & $\begin{array}{l}\text { forum diskusi yang dapat membantu meningkatkan } \\
\text { pemahaman mahasiswa }\end{array}$ & $2 \%$ & $10 \%$ & $35 \%$ & $42 \%$ & $11 \%$ \\
\hline C5 & $\begin{array}{l}\text { dapat diakses dengan mudah oleh dosen dan } \\
\text { mahasiswa }\end{array}$ & $6 \%$ & $16 \%$ & $27 \%$ & $36 \%$ & $14 \%$ \\
\hline C6 & $\begin{array}{l}\text { menyediakan berbagai informasi yang bermanfaat } \\
\text { mengenai proses pembelajaran }\end{array}$ & $1 \%$ & $3 \%$ & $14 \%$ & $48 \%$ & $34 \%$ \\
\hline C7 & $\begin{array}{l}\text { merupakan alat bantu yang menyediakan berbagai } \\
\text { kemudahan dalam penggunaannya }\end{array}$ & $2 \%$ & $6 \%$ & $28 \%$ & $51 \%$ & $13 \%$ \\
\hline C8 & $\begin{array}{l}\text { dapat diakses melalui berbagai web browser } \\
\text { apapun yang tersedia di pasaran }\end{array}$ & $3 \%$ & $8 \%$ & $24 \%$ & $42 \%$ & $23 \%$ \\
\hline
\end{tabular}

Pada pernyataan C1 pada aspek Hambatan dalam Binus Maya, lebih dari 47\% responden menyatakan setuju bahwa Binus Maya masih cukup menjadi alat bantu komunikasi dalam proses pembelajaran, walau ada $4 \%$ yang tidak setuju dari sisi mahasiswa.

Pada pernyataan C2 pada aspek Hambatan dalam Binus Maya, 42\% responden mahasiswa menyatakan bahwa Binus Maya menjadi alat bantu pembentukan komunitas bagi dosen dan mahasiswa.

Pada pernyataan C3 pada aspek Hambatan dalam Binus Maya, 41\% responden mahasiswa menyatakan bahwa forum diskusi cukup dapat membantu meningkatkan minat belajar.

Pada pernyataan C4 pada aspek Hambatan dalam Binus Maya, 42\% responden mahasiswa menyatakan bahwa forum diskusi cukup dapat membantu meningkatkan pemahaman mahasiswa dalam proses belajar mengajar di luar kelas.

Pada pernyataan C5 pada aspek Hambatan dalam Binus Maya, 36\% responden mahasiswa dapat cukup mengakses Binus Maya dengan mudah oleh dosen dan mahasiswa.

Pada pernyataan C6 pada aspek Hambatan dalam Binus Maya, 48\% responden mahasiswa menyatakan bahwa Binus Maya cukup menyediakan berbagai informasi yang bermanfaat mengenai proses pembelajaran.

Pada pernyataan C7 pada aspek Hambatan dalam Binus Maya, 51\% responden Mahasiswa menyatakan bahwa Binus Maya cukup menjadi alat bantu yang menyediakan berbagai kemudahan dalam penggunaannya.

Pada pernyataan C8 pada aspek Hambatan dalam Binus Maya, 42\% responden mahasiswa menyatakan bahwa Binus Maya cukup dapat diakses melalui berbagai web browser apapun yang tersedia di pasaran. 
Dari ke delapan point pada aspek ini, dapat diambil simpulan bahwa Binus Maya masih cukup mengalami hambatan dalam fungsinya seperti dalam belum dapat menjadi alat bantu komunikasi yang baik, pembentukan komunitas bagi dosen dan mahasiswa, forum diskusi cukup dalam membantu minat belajar dan juga terutama dalam akses internet pada situs Binus Maya yang masih perlu ditingkatkan lagi dalam penggunaan fungsi Binus Maya sebagai proses belajar mengajar di luar kelas.

\section{PENUTUP}

Dari pembahasan di atas, dapat disimpulkan hal-hal sbb: (1) untuk mensukseskan pembelajaran e-learning, yang perlu diperhatikan adalah media aplikasi yang digunakan harus diketahui dengan baik oleh target pemakai, sehingga akan lebih mudah untuk melakukan internalisasi kebijakan dan budaya baru. Khususnya terkait aplikasi binusmaya, sebagaian besar user (lebih dari $60 \%$ ) sudah mengetahui cara akses binusmaya dengan baik; (2) saat ini hambatan yang paling, besar adalah kesulitan untuk dapat diakses (lambat ketika membuka dan mendownload), kurang memicu minat belajar, dan kurang menarik untuk membantu pembentukan komunitas belajar; (3) harapan yang disampaikan lebih kepada tampilan yang lebih menarik, cara akses yang lebih mudah, tertempel (embedded) dengan social media ataupun smartphone.

\section{DAFTAR PUSTAKA}

Aprina. (2008). Penerapan e-learning vs blended learning di dalam pembelajaran jarak jauh. Mini Paper Sistem Informasi Manajemen.

Dziuban, Charles D. (2004). Blended learning. EDUCAUSE Center for Applied Research, 2004 (7).

Garrison, Randy D., Vaughan, Norman D. (2008). Blended learning in Higher Education. San Fransisco: Wiley. 